\title{
ETHYL SILICATES WITH DIFFERENT HYDROLYSIS DEGREE LIKE NON-FLAMMABLE IMPREGNATING MATERIAL FOR WOOD
}

\author{
SILICATOS DE ETILO CON DIFERENTE GRADO DE HIDRÓLISIS COMO \\ MATERIAL IMPREGNANTE IGNÍFUGO PARA MADERAS
}

\author{
Andrea M. Pereyra, Carlos A. Giudice \\ CIDEPINT (Centro de Investigación y Desarrollo en Tecnología de Pinturas), calle 52 e/121 y 122, \\ (1900) La Plata, Argentina
}

UTN-FRLP (Universidad Tecnológica Nacional Facultad Regional La Plata), calle 60 y 124, (1900) La Plata, Argentina

Corresponding author:cagiudice@yahoo.com

Received: 24.08. 2007. Accepted: 29.04. 2008.

\begin{abstract}
The wood, like other materials, cannot indefinitely resist the action of the fire without undergoing deterioration. In this work, low-density wood panels were impregnated with partially hydrolyzed ethyl silicates
\end{abstract}

The results obtained in laboratory, with different degree of penetration and retention of the impregnant material, showed through tests in a Horizontal-Vertical Cabinet, a LOI Chamber and an Inclined Tunnel a high fire retardant efficiency.

Key words: wood, impregnation, ethyl silicate, retention, penetration, fire resistance

\section{RESUMEN}

La madera, al igual que el resto de los materiales, no puede resistir indefinidamente la acción del fuego sin sufrir deterioro. En este trabajo se estudió el comportamiento de paneles de madera de baja densidad impregnadas con silicatos de etilo parcialmente hidrolizados.

Los resultados obtenidos en laboratorio, con diferentes grados de penetración y retención del impregnante, mostraron a través de ensayos en una Cabina Horizontal-Vertical, en una Cámara LOI y en un Túnel Inclinado una alta eficiencia retardante del fuego.

Palabras clave: madera, impregnación, silicato de etilo, retención, penetración, resistencia al fuego 


\section{INTRODUCTION}

The products based on silicates can be classified according to which the curing is carried out by chemical reaction or heat treatment (inorganic silicates) or by self-curing (inorganic and organic silicates) (Giudice, 1989).

The use of soluble alkaline silicates is varied and it goes back many years (detergents, water purification, adhesives, zinc-rich coatings, etc.); in the field of fire retardancy, the alkaline silicates were also used in the formulation of non-flammable coatings and varnishes.

To make fire-resistant to the wood, soluble alkaline silicates were also used with a subsequent treatment with solutions of metallic salts to make the alkaline silicates insoluble (Lilla, 1976); later, on the basis of the previous method, other patents were developed (Shiozawa, 1995; Slimak et al. 2000; Slimak and Slimak, 2000; Grantham and Warren, 2001).

However, in all of these cases, the silicate-based treatment compositions can be leached from the wood by exposure to environmental water and moisture, which eventually causes that the treated wood loses its resistance against fire action.

Many authors (Furuno et al. 1992; Furuno et al. 1993; Saka et al. 1992; Yamaguchi, 1994; Yamaguchi, 1994) carried out study based on a lot of inorganic composites to improve the performance of wood (biocide action, fire resistance, etc.).

In a previous unpublished paper by Giudice et al., the fire-retardant performance of a low-density wood (Araucaria angustifolia) impregnated with sodium silicates and potassium silicates (2.5/1.0 and 3.0/1.0 silica/alkali mole ratios) was studied. To facilitate silicate polymerization inside pores of the wood, different treatments were considered. The results indicated that heating at $90{ }^{\circ} \mathrm{C}$ for 24 hours and acid treatment were insufficient to make the silicates insoluble or at least of reduced solubility.

In other paper of the same authors, the silicates used were of higher silica/alkali ratio than in the previous experiments; an acid treatment was also used to form, in the first stage, a silicic polymer of elevated molecular weight and then, in the second stage, a treatment with cations (aluminum, copper, zinc, magnesium and calcium) to form a metallic silicic polymer of high insolubility. Results allowed also concluding that the soluble alkaline silicates previously treated with an acid and then with cations lead to the formation of metal silicate polymers, which show reduced water-solubility; the last one avoids the leaching of impregnant in contact with water and besides assures the keeping of fire-resistant ability in use.

It is very important to mention a significant advantage of the alkaline silicates for the treatment of woods, beyond those before quoted such as the high retardant efficiency and the minimum thermal expansion: their reduced generation of smoke during the conflagration without any toxicity for the alive beings; their low cost constitutes another excellent factor.

Other treatments for wood were carried out with various inorganic silicon compounds (silicofluorides, colloidal silicic acid solutions combined with various metal compounds or boric acid) as preservatives or biocides; they showed good performance. Water glasses also enhanced the durability of wood (Mai et al. 2004; Yamaguchi, 2002).

Other authors treated the wood with different alkoxysilanes and silanes; wood properties such as cell wall bulking, anti-swelling efficiency, moisture uptake and durability were more significantly improved in samples treated. (Donath et al. 2004). However, the behaviour against fire of quoted treatments for wood was no reported.

On the other hand, other authors studied the influence of $\mathrm{SiO}_{2}$ impregnated in wood against fire; this treatment showed to be no stable and easily leached out. However, the authors demonstrated that a small addition of alkoxysilanes could restrain the fire-resisting agents to be leached from the composite (Saka and Ueno, 1997).

It is very important to mention that among the essential disadvantages of soluble alkaline silicates is 
the high alkalinity of the solutions that demands a special care for their manipulation; for these reasons organic silicates were considered as impregnant in this paper.

In these cases and depending on the alkyl group, solvents usually employed are alcohols and aromatic hydrocarbons. Generally, the elimination of the solvent is completed between 5 and 10 minutes. The alkyl silicates cure by reaction with the steam by internal reactions of silicification.

Particularly the ethyl silicates are frequently used to elaborate coatings based on metallic zinc for the anticorrosive protection of substrates of iron and steel (Parashar et al. 2001). The experience gained in this field indicates that the curing takes place inclusive a very low temperatures; thus, for example, ethyl silicates in film form silicificate in approx. 7 days to $-15^{\circ} \mathrm{C}$; in 3 days to $0{ }^{\circ} \mathrm{C}$; in 1 day to $20^{\circ} \mathrm{C}$ and 30 hours between 15 and $18^{\circ} \mathrm{C}$. The hydrolysis reaction involves the elimination of the alcohol generated by chemical reaction with the air humidity; they do not cure to temperatures superior to $100^{\circ} \mathrm{C}$.

For the present study, considering the inorganic characteristics and the excellent physical-mechanical properties of the zinc-alkyl silicate films, ethyl silicates with different hydrolysis degrees were selected to impregnate panels of a porous wood (Araucaria angustifolia) with the purpose of improving the behavior against fire action.

\section{MATERIALS AND METHODS}

Partially hydrolyzed ethyl silicates formulation and manufacture. The alkyl silicates, as mentioned, display changes during the curing process; these changes involve hydrolysis reactions, Figure 1.

In the initial stage of hydrolysis, the polymer has sufficient organic groups that confer solubility; in the evolution of the reaction, the organic groups hydrolyze themselves gradually and consequently the silicates are transformed in a totally inorganic material.

The hydrolysis degree in solution can be calculated considering the stoichiometric amounts of silicates and water added.

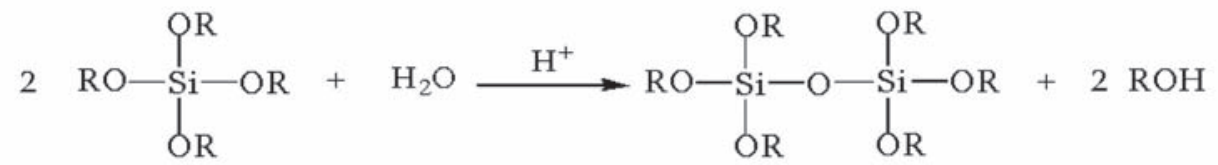

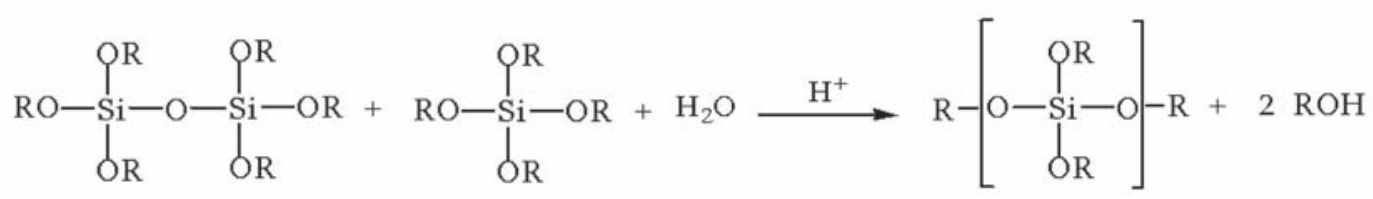

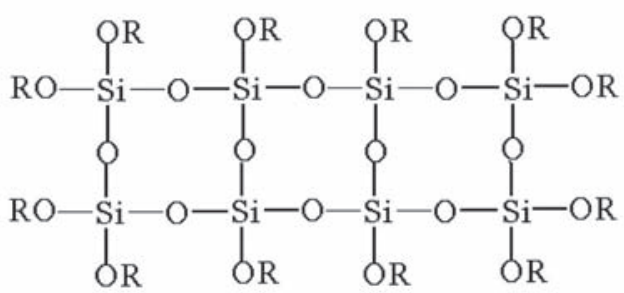

Figure 1. Curing reactions of alkyl silicates 
The rate to which the drying and the curing take place is strongly influenced by the temperature. The initial evaporation of the solvents is faster as temperature increases; as mentioned, in the hydrolyses the curing reactions depend on the possibility that the steam of the air condenses on alkyd silicates. The temperature influences the polymeric structure and consequently also the final properties.

With respect to their manufacture, the ethyl silicates (usual denomination of the derivatives of the tetraethyl orthosilicate) are synthesized from silicon tetrachloride and the anhydrous ethyl alcohol, Figure 2. These products commercialize like condensed ethyl silicates that contain approximately 28 $\% \mathrm{w} / \mathrm{w} \mathrm{SiO}$ and at least $90 \% \mathrm{w} / \mathrm{w}$ monomer. The additional purification eliminates residual products of low boiling point (mainly ethanol) and the dimmers, trimmers, etc.; this treatment allows obtaining pure ethyl silicates conformed by $99 \% \mathrm{w} / \mathrm{w}$ monomer.

$$
\mathrm{SiCl}_{4}+4 \mathrm{C}_{2} \mathrm{H}_{5} \mathrm{OH} \longrightarrow\left(\mathrm{C}_{2} \mathrm{H}_{5}\right)_{4} \mathrm{SiO}_{4}+4 \mathrm{ClH}
$$

Figure 2. Reaction of formation of the tetraethyl ortosilicate

Theoretically, the complete hydrolysis of ethyl silicates generates silica and ethyl alcohol, Figure 3 . Nevertheless, the real hydrolysis never produces silica in form of $\mathrm{SiO}_{2}$ (diverse intermediate species of polysilicates are generated).

As the reaction advances, the molecular weight and the length of the chains of these polysilicates increase until the majority (or the totality) of the ethyl groups is evacuated: the network $\equiv \mathrm{Si}-\mathrm{O}-\mathrm{Si} \equiv$ of three-dimensional characteristics is formed. This phenomenon produces as the liquid mixture of ethyl silicates / water becomes more viscous (gelification).

$$
\left(\mathrm{C}_{2} \mathrm{H}_{5}\right)_{4} \mathrm{SiO}_{4}+2 \mathrm{H}_{2} \mathrm{O} \stackrel{\begin{array}{c}
\text { Acid or } \\
\text { alkaline }
\end{array}}{\longrightarrow} \mathrm{SiO}_{2}+4 \mathrm{C}_{2} \mathrm{H}_{5} \mathrm{OH}
$$

Figure 3. Complete hydrolysis of tetraethyl ortosilicate

Consequently, through a partial hydrolysis under controlled conditions it is possible to obtain a stable mixture of a polysilicates prepolymer. Figure 4 shows the stoichiometric equation that allows calculating the hydrolysis degree $\mathrm{X}$.

$$
\mathrm{Si}(\mathrm{OR})_{4}+2 \mathrm{H}_{2} \mathrm{O} \stackrel{\begin{array}{c}
\text { Acid or } \\
\text { alkaline }
\end{array}}{\longrightarrow}\left[\mathrm{Si}(\mathrm{OR})_{4(1-X)} \mathrm{O}_{2 X}\right]+4 \mathrm{X} \mathrm{ROH}
$$

Figure 4. Equation that interprets the hydrolysis degree of alkyl silicates 
The hydrolysis processes of ethyl silicates, in the presence of acid or alkaline catalysts, produce partially hydrolyzed ethyl silicates, with a predetermined degree X. The variables that influence are the amount of catalyst, the water level, type and content of organic solvent, the temperature and the time of reaction. The pure or condensed ethyl silicates do not display good properties to form a polymeric material of inorganic nature. In this paper, ethyl silicates were prepared with different hydrolysis degree in an acid medium (Figure 5) since in previous laboratory test the catalyses carried out in alkaline one lead to a fast gelification.

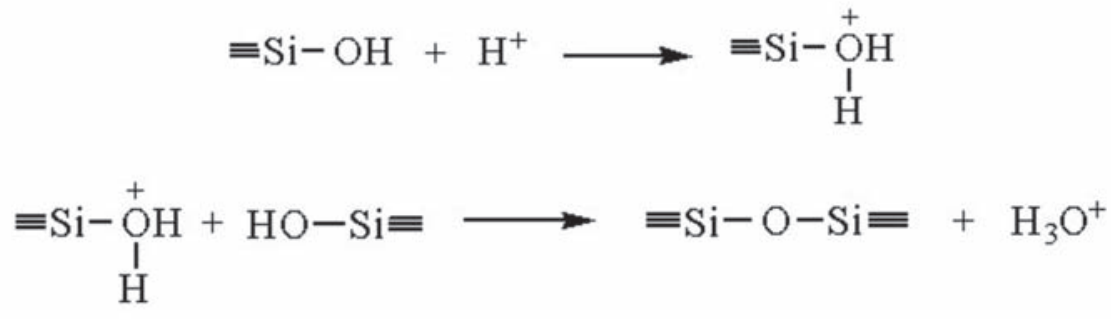

Figure 5. Reaction of condensation through the protonated hydroxyl groups

In this study, a condensed commercial tetraethyl orthosilicate, with the characteristics indicated in Table 1 , was selected.

The empirical equation of ethyl silicates hydrolyzed with a degree $\mathrm{X}$ was used to estimate the weight of the ethyl polysilicate and the hydrolysis degree, through the calculation of the necessary amount of water. The weight was obtained replacing the atomic weights in the mentioned empirical formula; the result indicates that the same one is equal to 208 - $148 \mathrm{X}$ (Parashar et al. 2001).

The percentual concentration of the silicon dioxide in the ethyl polysilicates is equal to the relation molecular weight of $\mathrm{SiO}_{2}$ x 100 / weight of the ethyl polysilicates; consequently, $\% \mathrm{SiO}_{2}=60$ x $100 /(208$ - $148 \mathrm{X}$ ). On the other hand, to calculate the water amount for a given weight of tetraethyl orthosilicate and with the purpose of preparing a solution of a predetermined hydrolysis degree, the equation weight of water $=36(100 \mathrm{X}) / 208$ was used.

Table 1. Properties of the condensed ethyl orthosilicate

\begin{tabular}{cc}
\hline Aspect & Colorless liquid \\
Density, kg.m ${ }^{-3}\left(20^{\circ} \mathrm{C}\right)$ & 928 \\
Flash point, ${ }^{\circ} \mathrm{C}$ & 54 \\
Boiling point, ${ }^{\circ} \mathrm{C}$ & 175 \\
Freezing point, ${ }^{\circ} \mathrm{C}$ & -76 \\
Viscosity, cP $\left(20^{\circ} \mathrm{C}\right)$ & 0.75 \\
Silicon content, $\%$ & 28.0 \\
Monomer content, $\%$ & 92.0 \\
Molecular weight & 208 \\
\hline
\end{tabular}


In addition, in the final stage of preparation of the impregnating material, the amount of isopropyl alcohol necessary to fit to a same percentual level the silica content was calculated; it is possible to mention that after finishing the first hydrolysis stage of tetraethyl orthosilicate that leads to the silicic acid formation, the alcohol absence would generate the polycondensation of mentioned acid with silica precipitation and the null capacity to conform a polymeric silicic acid.

Partially hydrolyzed ethyl silicates were prepared with values of $X$ of $0.20 ; 0.40 ; 0.60$ and 0.80 to be used like impregnating for wood, with the purpose of improving their behavior against fire; Table 2 indicates the amount of distilled water ( $\mathrm{g} / 100 \mathrm{~g}$ of pure tetraethyl orthosilicate) necessary to reach the predetermined hydrolysis degree and Table 3 shows the composition of the impregnating material with different percentual silica levels.

Later, the solvent amount to add (expressed like anhydrous isopropyl alcohol, in $\mathrm{g} / 100 \mathrm{~g}$ ) to obtain in all the cases final silica content in the impregnating material of $15 \%$ was also calculated, Table 4.

With respect to the manufacture, the pure tetraethyl orthosilicate was firstly mixed with the isopropyl alcohol. Then, the water and $\mathrm{ClH}$ selected as catalyst were added (final $\mathrm{pH}$ of the impregnating solution was slightly acid, $0.01 \%$ of $\mathrm{ClH} \mathrm{w} / \mathrm{v}$ ); the hydrolysis displayed an exothermic characteristic. In all the cases, the impregnants were used 24 hours after concluding their manufacture; surface tension was previously adjusted with a tensioactive agent (sodium dodecyl sulphate) until getting a value of 40 dyne.cm ${ }^{-1}$ to $20^{\circ} \mathrm{C}$.

Table 2. Hydrolysis of condensed tetraethyl orthosilicate

\begin{tabular}{|c|c|c|c|c|}
\hline \multirow{2}{*}{ Composition } & \multicolumn{4}{|c|}{ Hydrolysis degree } \\
\cline { 2 - 5 } & $\mathbf{X = 0 . 2 0}$ & $\mathbf{X = 0 . 4 0}$ & $\mathbf{X = 0 . 6 0}$ & $\mathbf{X = 0 . 8 0}$ \\
\hline $\mathbf{S i O}_{\mathbf{2}}, \%$ w/w in polysilicates & 33.6 & 40.3 & 50.3 & 67.0 \\
\hline $\begin{array}{c}\text { Water added, \% w/w on pure } \\
\text { tetraethyl orthosilicate }\end{array}$ & 3.5 & 7.0 & 10.4 & 13.8 \\
\hline
\end{tabular}

The experience indicates that an excessive amount of water (superior to the calculated one) generates a fast gelification in the package, with the consequent loss of the impregnating ability.

In addition, an elevated $\mathrm{pH}$ leads to a fast silica precipitation and besides to a diminishing of the capacity of formation of an inorganic polymer of elevated molecular weight.

On the other hand, an amount very elevated of acid slows down the reaction of condensation by repulsion of the protonated hydroxyl groups; thus, for example, for $\mathrm{pH}$ values inferior to 5 , inclusive for the greatest considered hydrolysis degree, the curing of an impregnating material film ( $80 \pm 5 \mu \mathrm{m}$ dry film thickness) in laboratory conditions $\left(20^{\circ} \mathrm{C}\right.$ and $\left.65 \% \mathrm{HR}\right)$ was not completed in a lapse of 72 hours. 
Table 3. Composition of partially hydrolyzed impregnating material, $\% \mathrm{w} / \mathrm{w}$

\begin{tabular}{|c|c|c|c|c|}
\hline \multirow{2}{*}{ Composition } & \multicolumn{4}{|c|}{ Hydrolysis degree } \\
\cline { 2 - 5 } & $\mathbf{X = 0 . 2 0}$ & $\mathbf{X = 0 . 4 0}$ & $\mathbf{X}=\mathbf{0 . 6 0}$ & $\mathbf{X}=\mathbf{0 . 8 0}$ \\
\hline $\mathbf{S i O}_{2}$ & 27.9 & 27.0 & 26.1 & 25.3 \\
\hline Polysilicates & 82.9 & 66.9 & 51.9 & 37.8 \\
\hline Ethyl alcohol & 17.1 & 33.1 & 48.1 & 62.2 \\
\hline
\end{tabular}

Zinc cation - polymeric silicates reaction. The silanol groups of organic silicates react with di- and tri-valent cations to form metal-silanol heterobridges; later, the last ones react to give polymers of metallic silicates, Figure 6.

Table 4. Amount of anhydrous isopropyl alcohol added to uniform the silica level to $15 \%$ in the impregnating material

\begin{tabular}{|c|c|c|c|c|}
\hline & \multicolumn{4}{|c|}{ Hydrolysis degree } \\
\cline { 2 - 5 } $\begin{array}{c}\text { Isopropyl alcohol, } \\
\text { g/ 100 g of } \\
\text { impregnant }\end{array}$ & $\mathbf{X = \mathbf { 0 . 2 0 }}$ & $\mathbf{X}=\mathbf{0 . 4 0}$ & $\mathbf{X = \mathbf { 0 . 6 0 }}$ & $\mathbf{X}=\mathbf{0 . 8 0}$ \\
\cline { 2 - 5 } & 86.0 & 80.0 & 74.0 & 68.7 \\
\hline
\end{tabular}

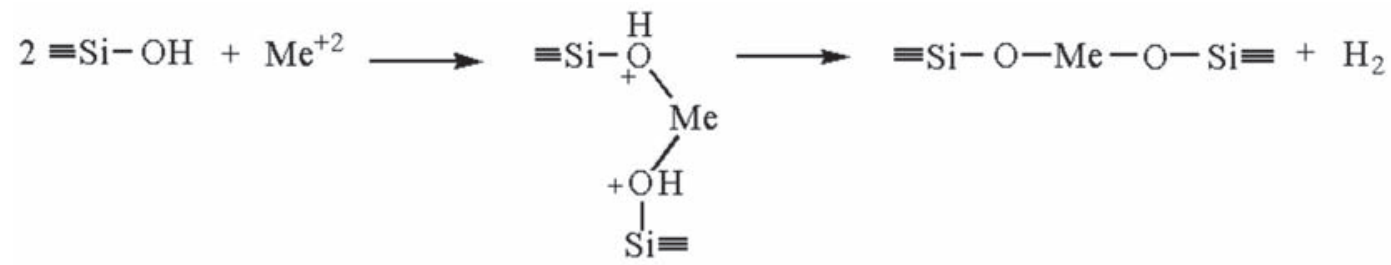

Figure 6. Formation of a polymer of metallic silicates

In the present work, films of different impregnating solutions applied on glass were sprayed with a $10 \%$ zinc sulphate solution. These films, after curing for 7 days in laboratory $\left(20^{\circ} \mathrm{C}\right.$ and $\left.65 \% \mathrm{HR}\right)$, displayed null or minimum distilled water solubility.

The first stage would involve the formation of the silicic acid of high molecular weight; the second reaction would include the formation of polymers of metallic silicates from silicic acid and the divalent cation, Figure 7. 
Operative conditions of the impregnating process. The impregnating of the wood depends on a great number of factors, among them its anatomy, the previous preparation and the procedure used for the impregnating (Horrocks et al. 2001). Testing panels for these experiments were prepared on Araucaria angustifolia since it is a porous wood, that is of low-density $\left(497 \mathrm{~kg} \cdot \mathrm{m}^{-3}\right)$ and easily penetrable.<smiles></smiles>

Figure 7. Polymer structure of metallic silicates

With the purpose of achieving a good impregnation (Baysal et al. 2006; Grexa et al. 1999; Imamura, 2001), the mentioned testing panels were kept under laboratory conditions until moisture contents of between 15 and $18 \%$ were reached (Usta, 2006). The impregnations were carried out at $20{ }^{\circ} \mathrm{C}$ in a vertical pressure vessel of 25 liters capacity, provided with a vacuum pump and an air compressor. In all the cases, the vessel was loaded with the test panels to be impregnated; then the pressure was reduced by $400 \mathrm{~mm} \mathrm{Hg}$ for 30 minutes to remove air and vapor from the wood cells. Subsequently, the impregnants were added without decreasing the vacuum level until ratio of wood/solution was $1 / 3^{\text {rd }}$ by volume.

Later on, the pressure was gradually increased until a final value of $6.5 \mathrm{~kg} . \mathrm{cm}^{-2}$ to facilitate the penetration; this stage lasted for 120 minutes. The wood/solution ratio that was selected ensured that in all the cases the test panels were completely submerged in the solution of the impregnant for the duration of the process (Series A); the next stage consisted of creating a slight vacuum (approximately $20 \mathrm{~mm} \mathrm{Hg}$ for 10 minutes) to eliminate the excess of soluble silicates.

Other panels (Series B), after finalizing the impregnation in the operative conditions above-mentioned, were remained in the vessel; then, $10 \%$ zinc chloride solution was added. The pressure and the working time as well as the relative volume of the solutions with respect to the panels were comparable to the above-mentioned in the alkyl silicates impregnation; in similar way to the previous Series A, at the end of the process a slight vacuum was also carried out for the elimination of the zinc solution excess.

Finally, after reducing the pressure, the test panels were removed and rinsed with distilled water. Before starting the tests to establish their behavior in fire, a set of panels was air-dried for 7 days under laboratory conditions $\left(20-22{ }^{\circ} \mathrm{C} ; 50-55 \% \mathrm{HR}\right)$ until reaching constant weight (Group I). Another set of panels was also air-dried under the same laboratory conditions, then submerged in distilled water for 48 hours and finally air-dried until reaching the equilibrium moisture content (Group II) (Dietzel, 2000; Papisova et al. 1999).

For reference, wood panels (Araucaria angustifolia) without any treatment were also tested. The identification of the samples is indicated in Table 5. 
Table 5. Samples identification

\begin{tabular}{|c|c|c|}
\hline Curing type & Silicates & Identification \\
\hline \multirow{2}{*}{$\begin{array}{c}\text { Series A } \\
\text { (Silicification, without } \\
\text { Zn cation) }\end{array}$} & $1 . \mathrm{X}=0.20$ & $\mathrm{~A} .1$ \\
\cline { 2 - 3 } & $2 . \mathrm{X}=0.40$ & $\mathrm{~A} .2$ \\
\cline { 2 - 3 } & $3 . \mathrm{X}=0.60$ & $\mathrm{~A} .3$ \\
\hline \multirow{3}{*}{$\begin{array}{c}\text { Series B (Silicification, } \\
\text { with Zn cation) }\end{array}$} & $4 . \mathrm{X}=0.80$ & $\mathrm{~A} .4$ \\
\cline { 2 - 3 } & $1 . \mathrm{X}=0.20$ & $\mathrm{~B} .1$ \\
\cline { 2 - 3 } & $2 . \mathrm{X}=0.40$ & $\mathrm{~B} .2$ \\
\hline Reference & $3 . \mathrm{X}=0.60$ & $\mathrm{~B} .4$ \\
\hline
\end{tabular}

Group I: Air-dried panels under laboratory conditions

Group II: Air-dried panels under laboratory conditions and then submerged in distilled water for 48 hours

Fire-retardant tests. Three fire tests were carried out to provide comparative measurements of the fire performance of the untreated and treated wood samples.

- Two Foot Tunnel: Results from this test included a Flame spread index (FSI) and a Panel consumption (PC) (Caciolai, 1999; Shaw, 1999). The top of the apparatus is a $600 \mathrm{~mm} \times 100 \mathrm{~mm}$ section constructed of angle iron and inclined $28^{\circ}$ from the horizontal. The $610 \mathrm{~mm}$ long, $100 \mathrm{~mm}$ wide, $10 \mathrm{~mm}$ thick testing panels of Araucaria angustifolia were prepared and placed in the opening. A $215 \mathrm{~mm}$ high, 40 $\mathrm{mm}$ diameter natural gas burner is inserted in the enclosed space below the specimen to provide the fire exposure for 4 minutes. Based on measurements taken every 15 seconds in the first 4 minutes, the average of the three highest consecutive readings of the flame advance in millimeters was calculated. In addition, the samples were weighed before and after the test. An asbestos-cement board (zero flamespread) is also tested. For this study, the FSI of the panels was computed by using the equation FSI = (Ls - Lo) / ( Lb - Lo), where Ls is the average of the three flame-advance readings for the test specimen, Lo the average of three flame-advance readings for the zero flame spread board and Lb the average of three flame- advance readings for the untreated wood panels of Araucaria angustifolia. In ASTM $\mathrm{D} 3806, \mathrm{Lb}$ is the result for a known standard materials and this ratio is multiplied by the ASTM E 84 Flame spread index of the standard material. ASTM E 84 is the regulatory flame spread in the U.S. The weight loss in grams was reported as the Panel consumption.

- Limiting Oxygen Index, LOI: This test determines the minimum oxygen concentration that just support combustion of a material under equilibrium conditions as candle-like burning (ASTM D 2863). It is one of the favorite tests in the assessment of the fire retardant treatments of polymeric materials because it gives reproducible numerical results (Hindersinn, 1990). The LOI Chamber consists of a glass tube with a perforated plate and glass beads at the bottom that facilitates the mixing of the oxygen and the nitrogen, a clip to support the sample of test panel, devices for controlling and measuring the gases (filters, gauges, microvalves, flow meters, etc.) and a propane flame ignition system. A 150 x 10 x $10 \mathrm{~mm}$ specimen was clamped vertically on the approximate centerline of the column with the upper edge of the sample at least $100 \mathrm{~mm}$ below the top of the open glass column. Then, the flow valves were set so that the desired concentration of oxygen flows through the glass column. The total flow rate was $3.2 \mathrm{~cm} . \mathrm{s}^{-1}$. After purging the system with the oxygen-nitrogen flow for 30 seconds, the top of the specimen was ignited with the propane flame so that the top of the test specimen was well alight. If the specimen continued to 
burn after the igniter flame was removed, a new specimen was inserted and the oxygen concentration was adjusted to a lower level. If the specimen did not continue to burn, the oxygen concentration was increased to an intermediate value for the subsequent specimen. Testing continued until the minimum oxygen concentration was established. The determination of the LOI was done in triplicate.

- Resistance to the intermittent flame of a Bunsen burner, RIB: The testing wood panels of Araucaria angustifolia $(200 \times 100 \times 3 \mathrm{~mm})$ were arranged in a Flame Cabinet according to UL 94 (Underwriters Laboratories Standard). The longitudinal axes of the coated panels were set with an inclination of 45 degrees with respect to the supporting level while their transversal axes were in a parallel position.

The test done in triplicate consisted in submitting the front bottom part of the test panel to the intermittent flame of a Bunsen burner vertically disposed. Flame was adjusted so as to reach $10 \mathrm{~mm}$ height of blue cone. The exit hole of the burner was arranged at $25 \mathrm{~mm}$ of the testing surface.

The panel, in the above-mentioned position, was submitted to flame action for 20 seconds, with resting periods of 10 seconds (first stage). When the number of cycles of extinguishable behaviour reached the value 25 , the action of the flame lasted for 50 seconds with resting periods of 10 seconds (second stage). The exposure fire / resting cycle was repeated in both stages until the flame did not extinguish within five seconds or the carbonised zone did not exceed $8 \mathrm{~cm}^{2}$ after that burner flame was shut off.

Finally, if panels continued pronouncing like extinguishable after other 25 cycles in the mentioned second stage, the flame stayed in constant way during 5 minutes as maximum (third stage); in this case, the test was finished when the carbonised zone exceed $8 \mathrm{~cm}^{2}$.

The number of cycles with extinguishable behaviour was determined; the qualification of the first two stages was carried out with two and six points respectively while the third one was made with ten points by every minute.

Then, the whole amount of points for each panel and the average of the three panels were calculated. The qualification and classification of panels were done according to what is established in Table 6 .

\section{RESULTS AND CONCLUSIONS}

Retentions and penetrations. After completing the treatment, the retentions were calculated gravimetrically while the penetrations were carried out through visual and microscopic observations of cuts on the test panels (Gindl et al. 2003).

The retention, which is the quantity of solids from the impregnant solution absorbed by unit of volume of wood, lay in the narrow margin between 110 and $115 \mathrm{~kg} \cdot \mathrm{m}^{-3}$; the average value for all treated woods was of $112 \mathrm{~kg} \cdot \mathrm{m}^{-3}$.

Concerning penetration (the depth reached by the impregnant solution), this was full thickness for $90 \%$ of the cases while in the remaining $10 \%$, the penetration was slightly irregular. Final average density of the test panels after impregnation was $535 \mathrm{~kg} \cdot \mathrm{m}^{-3}$.

Performance in the fire tests. Experimental results are shown in Tables 7 and 8 . With the aim of determining the performance of each variable, in a first stage the values of FSI, PC, LOI and RIB were established in a scale that ranged between 0 and 10 . Thereby, the values 0 and 10 were respectively assigned to 1.00 and 0.00 (FSI); to $7.38 \%$ and $0.00 \%$ (PC), to 16 and $\geq 50$ (LOI) and finally to 0 and 250 (RIB); it is important to mention that in all cases, value 0 corresponded to the lowest one obtained in each test. 
Table 6. Qualification and classification of the panels

\begin{tabular}{|c|c|c|}
\hline $\begin{array}{c}\text { Average rating in } \\
\text { Intermittent flame test }\end{array}$ & Qualification & Classification \\
\hline 200 to 250 & Passed & Class A \\
\hline 150 to 199 & Passed & Class B \\
\hline 100 to 149 & Failed & Class C \\
\hline 99 or less & Failed & Class D \\
\hline
\end{tabular}

The performance against fire was statistically studied according to a factorial design of 4 hydrolysis degrees, 2 curing treatments (with and without the Zn cation) and 2 operative conditions (drying / curing to the air and after finishing this stage with later distilled water immersion), that is 16 combinations elaborated by triplicate.

The variance was calculated and later the Fisher F test was made. The results indicated that the variables considered (main effects): curing treatment and operative conditions exhibited an important influence on the efficiency against fire; on the other hand, the effect hydrolysis degree did not influence significantly on the panels performance.

The results including Tables 7 and 8 indicate that all the impregnated panels improved sensibly their performance in relation to those used as reference $\mathrm{R}$ (without treatment). The average values mentioned in Table 9 show that the panels corresponding to Group I (drying and curing to the air until reaching the equilibrium moisture) demonstrated in general a greater efficiency than those of Group II (drying and curing to the air with later distilled water immersion for 48 hours); in addition, Series A (without later treatment with the metallic cation) displayed an inferior fire resistance that Series B (curing with the zinc cation).

In addition, the Table 9 also indicates that the average results corresponding to the considered hydrolysis degrees were similar, which corroborates the reached conclusions applying Fisher $\mathrm{F}$ test. This behavior would be based in which the moisture of the wood, in equilibrium with the one of the atmosphere, would provide the amount necessary to reach in all the cases the complete hydrolysis of partially hydrolyzed ethyl silicates used like impregnants.

Based on before-mentioned results, an analysis by separated variables was made, Table 10. The last one indicates that in Series B, the Groups I and II practically displayed identical values whereas in the Series A, the Group I showed a better performance than the Group II. The quoted results would be based on which the curing treatment with a zinc salt in the second stage during the impregnating process would have lead to the polymeric silicates formation of reduced distilled water solubility, which was corroborated by determination of the alkaline cation in solution. 
Table 7. Results corresponding to Group I* (Drying and curing to air)

\begin{tabular}{|c|c|c|c|c|}
\hline Series A & FSI & PC, $\%$ & LOI, $\%$ & RIB \\
\hline A.1 & 0.26 & 2.87 & 46 & 200 \\
\hline A.2 & 0.28 & 2.72 & 48 & 200 \\
\hline A.3 & 0.28 & 2.82 & 47 & 200 \\
\hline A.4 & 0.27 & 2.91 & 48 & 200 \\
\hline Series B & FSI & PC, $\%$ & LOI, $\%$ & RIB \\
\hline B.1 & 0.30 & 2.87 & 50 & 200 \\
\hline B.2 & 0.28 & 2.80 & 48 & 200 \\
\hline B.3 & 0.30 & 2.91 & 49 & 200 \\
\hline B.4 & 0.29 & 2.72 & 47 & 200 \\
\hline R & 1.00 & 7.38 & 16 & 15 \\
\hline
\end{tabular}

* Average of three determinations

Table 8. Results corresponding to Group II*

(Drying and curing to the air with later distilled water immersion for 48 hours)

\begin{tabular}{|c|c|c|c|c|}
\hline Series A & FSI & PC, $\%$ & LOI, $\%$ & RIB \\
\hline A.1 & 0.40 & 4.54 & 38 & 125 \\
\hline A.2 & 0.42 & 4.65 & 39 & 125 \\
\hline A.3 & 0.41 & 4.43 & 37 & 150 \\
\hline A.4 & 0.40 & 4.65 & 39 & 125 \\
\hline Series B & FSI & PC, $\%$ & LOI, $\%$ & RIB \\
\hline B.1 & 0.28 & 2.87 & 48 & 200 \\
\hline B.2 & 0.31 & 2.80 & 49 & 200 \\
\hline B.3 & 0.26 & 2.91 & 48 & 200 \\
\hline B.4 & 0.27 & 2.72 & 50 & 200 \\
\hline R & 1.00 & 7.38 & 16 & 15 \\
\hline
\end{tabular}

* Average of three determinations 
Table 9. Statistical results

\begin{tabular}{|c|c|c|c|}
\hline \multicolumn{1}{|c|}{$\mathbf{X = 0 . 2 0}$} & $\mathbf{X = 0 . 4 0}$ & $\mathbf{X}=\mathbf{0 . 6 0}$ & $\mathbf{X}=\mathbf{0 . 8 0}$ \\
\hline 7.13 & 7.12 & 7.12 & 7.14 \\
\hline \multicolumn{2}{|c|}{ Series A } & \multicolumn{2}{|c|}{ Series B } \\
\hline \multicolumn{2}{|c|}{6.59} & \multicolumn{2}{|c|}{ Group II } \\
\hline \multicolumn{2}{|c|}{ Group I } & \multicolumn{2}{|c|}{6.61} \\
\hline \multicolumn{2}{|c|}{7.65} & \multicolumn{2}{c}{} \\
\hline
\end{tabular}

Table 10. Analysis of separated variables

\begin{tabular}{|c|c|c|c|}
\hline \multicolumn{2}{|c|}{ Series A } & \multicolumn{2}{c|}{ Series B } \\
\hline Group I & Group II & Group I & Group II \\
\hline 7.64 & 5.54 & 7.66 & 7.67 \\
\hline
\end{tabular}

\section{ACKNOWLEDGEMENTS}

The authors are grateful to CONICET (Consejo Nacional de Investigaciones Científicas y Técnicas), to UTN-FRLP (Universidad Tecnológica Nacional Facultad Regional La Plata) and to CICPBA (Comisión de Investigaciones Científicas de la Provincia de Buenos Aires) for their sponsorship for this research.

\section{REFERENCES}

American Society For Testig And Materials. 2006. Measuring The Minimum Oxygen concentration Support Candle - Like Combustion of Plastic. ASTM D 2863.

American Society For Testig And Materials. 1998. Standard Test Method de Small Scale Evaluation of Fire - Retardant Paints (2 Foot Tunnel method). ASTM D 3806.

American Society For Testig And Materials. 2005. Standard Test Method For Surface Burnig Characteristics of Burdine Materials ASTM E 84.

Baysal, E.; Sonmez, A.; Colak, M.; Toker, H. 2006. Amount of leaching and water absorption levels of wood treated with borates and water repellents. Bioresource Technology 97 (18): 2271-2279.

Caciolai, M. 1999. Testing resistance to fire. Anticorrosione 7 (25): 29-33.

Dietzel, M. 2000. Dissolution of silicates and the stability of polysilicic acid. Geochimica et Cosmochimica Acta 64 (19): 3275-3281.

Donath, S.; Militz, H.; Mai, C. 2004. Wood modification with alkoxysilanes. Wood Science and Technology 38: 555 - 556 
Furuno, T.; Shimada, K.; Uehara, T.; Jodai, S. 1992. Combinations of Wood and Silicate II. Woodmineral composites using water glass and reactants of barium chloride, boric acid, and borax, and their properties. Mokuzai Gakkaishi 38: 448-457.

Furuno, T.; Uehara, T.; Jodai, S. 1991. Combinations of Wood and Silicate I. Impregnation by water glass and applications of aluminum sulfate and calcium chloride as reactants. Mokuzai Gakkaishi 37: 462-472.

Furuno, T.; Uehara, T.; Jodai, S. 1993. Combinations of Wood and Silicate III. Some properties of wood-mineral composites using the water glass-boron compound system. Mokuzai Gakkaishi 39: 561-570.

Gindl, W.; Zargar-Yaghubi, F.; Wimmer, R. 2003. Impregnation of softwood cell walls with melamineformaldehyde resin. Bioresource Technology 87: 325-330.

Giudice, C. A. 1989. Pinturas ricas en zinc basadas en silicatos inorgánicos y orgánicos. Manual Propiedades y Control de Calidad de Pinturas y Recubrimientos. Editor Organización de los Estados Americanos, 179-191.

Grantham, R.; Warren Jr. J. S. 2001. Method of pressure treating boards. U.S. Pat. No. 6,235,349.

Grexa, O.; Horvathova, E.; Besinova, O.; Lehocky, P. 1999. Flame retardant treated plywood. Polymer Degradation and Stability 64:529-533.

Hindersinn, R. 1990. Historical aspects of polymer fire retardancy. Fire and polymers, G. Nelson Editor, ACS Symposium Series, Washington, 87-96.

Horrocks, A.; Price, D. 2001. (Editors) Fire Retardant Materials; CRC Press USA and Wood head Publishing Limited England, 9: 293-317.

Imamura, I. 2001. Effect of combined boron compounds and furfuryl alcohol treatment on termite and decay resistance in wood. High-performance utilization of wood for outdoor uses. Report on Research Project, Grant-In-Aid For Scientific Research 97-103.

Lilla, A. G. 1976. Product and method for forming in situ insoluble metal silicates in wood pores for fire retardation and preservation. U.S. Pat. No. 3,974,318.

Mai, C.; Militz, H . 2004. Modification of wood with silicon compounds. inorganic silicon compounds and sol-gel systems: a review. Wood Science and Technology 37 (5): 339-348.

Papisov, I.M.; Bolyachevskaya, K.I.; Litmanovich, A.A.; Matveenko, V.N.; Volchkova I.L. 1999. Structural effects in matrix polycondensation of silicic acid. European Polymer Journal 35: 20872094.

Parashar, G.; Srivastava, D.; Kumar, P. 2001. Ethyl silicate binders for high performance coatings. Progress in Organic Coatings 42 (1-2): 1-14.

Saka, S.; Sasaki, M.; Tanahashi, M. 1992. Wood-Inorganic Composites Prepared by Sol-Gel Processing I. Wood-inorganic composites with porous structure. Mokuzai Gakkaishi 38: 1043-1049

Saka, S.; Ueno, T. 1997. Several $\mathrm{SiO}_{2}$ wood-inorganic composites and their fire-resisting properties. Wood Science and Technology 31(6):457-466. 
Shaw, R. 1999. The use of flame retardant coatings on wall and ceilings. J. Oil Col. Chem. Assoc. 72 (5): 176-180.

Shiozawa, K. 1995. Wood preservative composition, process for treating wood with the same, wood treated with the same. U.S. Pat. No. 5,478,598.

Slimak, K. M.; Slimak, R. A. 2000. Enhancing the strength, moisture resistance, and fire-resistance of wood, timber, lumber, similar plant-derived construction and building materials, and other cellulosic materials. U.S. Pat. No. 6,146,766.

Slimak, R. A.; Haudenschild, C. C.; Slimak, K. M. 2000. Enhancing the strength, moisture resistance, and fire-resistance of wood, timber, lumber, similar plant-derived construction and building materials, and other cellulosic materials. U. S. Pat. No. 6,040,057.

Usta, I. 2006. Amenability of European silver fir (Abies alba Mill.) to preservative treatment by the full-cell process in longitudinal, tangential, radial and triplex flow pathways on the base of wood drying. Building and Environment 41(8): 1027-1033.

Yamaguchi, H. 1994. Properties of Silicic Acid Compounds as Chemical Agents for Impregnation and Fixation of Wood. Mokuzai Gakkaishi 40: 830-837.

Yamaguchi, H. 1994. Preparation and Physical Properties of Wood Fixed with Silicic Acid Compounds. Mokuzai Gakkaishi 40: 838-845.

Yamaguchi, H. 2002. Low molecular weight silicic acid - inorganic compound complex as wood preservative. Wood Science and Technology 36: 399-417. 
